\title{
Planting and harvesting innovation - an analysis of Samsung Electronics
}

\author{
Seung Hoon Jang ${ }^{{ }^{*}}$ (D), Sang M. Lee ${ }^{2}$, Taewan $\mathrm{Kim}^{3}$ and Donghyun $\mathrm{Choi}^{4}$
}

\author{
* Correspondence: SJANG@ \\ BLOOMU.EDU \\ ${ }^{1}$ Zeigler College of Business, \\ Bloomsburg University of \\ Pennsylvania, Bloomsburg, USA \\ Full list of author information is \\ available at the end of the article
}

\begin{abstract}
This study explores how firms manage the entire life cycle of innovation projects based on the framework of harvesting and planting innovation. While harvesting innovation seeks new products in the expectation of financial performance in the short term, planting innovation pursues creating value over a long time period. Without proper management of the process of planting and harvesting innovation, firms with limited resources may not be successful in launching innovative new products to seize a momentum in high tech industries. To examine this issue, the case of Samsung Electronics (SE), now an electronics giant originated from a former developing country, is analyzed. SE has shown to effectively utilize co-innovation to maintain numerous planting and harvesting innovation projects. Both researchers and practitioners would be interested in learning about how SE shared risks of innovation investment with external partners at the early stage of innovation cycles.
\end{abstract}

Keywords: Planting innovation, Harvesting innovation, Co-innovation, Multinationals, Case analysis

\section{Introduction}

Globalization and advances in technologies have made the global market extremely dynamic and competitive. While companies like Apple have created new customer value by introducing such products as iMac computer and iPhone, many other firms have failed to adapt to the fast-changing environment. Kodak, the creator of the film camera, became history since it failed to adapt to the digital era in a timely fashion. To compete successfully in the dynamic global market, organizations must continuously innovate ways to create value [1]. Thus, innovation has been an important topic to both management researchers and practitioners [2]. Many studies have explored the relationship between innovative activities and organizational performance $[3,4]$. The firm's ability of managing innovative projects has been considered as a key dynamic capability, resulting in new product development [5]. Innovative activities of the firm have generally shown to positively impact organizational outcome.

Although a number of studies in this research stream have introduced various types of innovation based on learning styles [6, 7] or objects [3], few have paid attention to the timing of financial return from innovation. Given the importance of financial payoff from innovation for firm survival and sustained competitive advantage, research on how a real business should manage both innovation and cash flow is critical. Thus, in this study, we intend to answer the following two research questions.

(c) The Author(s). 2019 Open Access This article is distributed under the terms of the Creative Commons Attribution 4.0 International License (http://creativecommons.org/licenses/by/4.0/), which permits unrestricted use, distribution, and reproduction in any medium, provided you give appropriate credit to the original author(s) and the source, provide a link to the Creative Commons license, and indicate if changes were made. 
RQ1: Which classification of innovation can best explain the heterogeneous timing of financial payoff realization?

To answer this question, we applied a classification scheme of planting and harvesting innovation $[8,9]$. Planting innovation involves pursuing potential sources of competitive advantage, including original technology, which may create value in a long term perspective. In contrast, harvesting innovation aims to develop new ways to monetize planted innovation, including new products for market launching, in the expectation of commercial success in a relatively short term. The aim of this research stream is to determine how to implement planting and harvesting innovation and measure the results of ensuing innovative activities. From this perspective, this study examines how a real global firm manages both types of innovation.

RQ2: How are planting and harvesting activities of innovation actually implemented in a successful global business firm?

To answer this question, we focus on Samsung Electronics (SE) which has become the world's largest electronics firm through successful planting and harvesting of innovation. While SE has developed many innovative new commercial products, it has focused on fundamental breakthrough technologies as the source of future growth momentum. This case may provide valuable implications for firms from developing economies. To compete in high tech industries, these businesses need to invest a large amount of capital to risky innovation projects. Otherwise, they may remain low value added entities, like assemblers or fast followers. The case of SE, like many other success stories, exhibits a possibility that multinationals originated from developing countries can become leading global firms based on their efforts and vision for breakthrough innovations.

Given the current turbulent global business environment, as observed by trade disputes between the USA and China and the recently disrupted supply of critical input resources from Japan to Korea, it is imperative for firms to develop core competences based on innovation. In the digital age, businesses must rely on innovation to enhance their dynamic capabilities [10] to enhance agility, flexibility, and resilience for value creation [1]. Thus, this study which focuses on the effective management of planting and harvesting innovation is expected to make important contributions to the literature.

This study examines how firms can implement innovation projects for both short- and long-term perspectives. For this purpose, we first reviewed the literature for major research streams of innovation. Then, a case method is used to examine how planting and harvesting of innovation have helped SE became a dominant global electronics firm, around 2012. In addition to secondary data, executive interviews reported in media also describe how SE employees implemented planting and harvesting innovation. The results of qualitative analyses are presented and articulated. Finally, the implications and limitations of this research are presented. The framework of planting and harvesting innovation provides a theoretical background on how firms can strive for both short-term cash flow and a long-term momentum despite their limited resources. Furthermore, the study results provide insights to practitioners through the case study of SE which struggled initially to save the cost of innovation by collaborating with external partners for planting and harvesting innovation. 


\section{Innovation under resource constraints}

\section{Planting versus harvesting innovation}

Researchers in various fields, including economics, sociology, and technology management, have been interested in innovation [11]. The characteristics of innovative outcomes have been investigated as a major research agenda [12, 13]. As Damanpour and colleagues [14] suggested, the introduction of novel ideas or technologies is the core of innovation. According to Van de Ven [15], innovation can be described as "the development and implementation of new ideas by people who over time engage in transactions with others within an institutional order ([15], p590)." Several definitions of innovation have focused on how to apply creativity to business operations and processes $[15,16]$. These studies imply that the main focus of innovation research has been on whether the firm creates new tangible or intangible values.

However, innovation has shown to lead to varied results. The meta-analysis by Rosenbusch et al. [17] reported that different contexts explain heterogeneous outcomes resulting from innovation. Even if firms implement similar innovation projects, the result can be different due to environmental factors. In addition, innovation sometimes improves the value of marketing skills rather than creating new technical capabilities $[18,19]$. What these results imply is that characteristics of innovative activities are complex. Since a single concept cannot explain the nature and outcome of innovation, researchers need to consider diverse classifications to explain the phenomena of innovation. Given the importance of cash flow in business, a greater focus is required on the influence of innovation on the survival and prosperity of the firm. Even when firms obtain breakthrough technologies, they may not survive when they fail to create new products/services and resulting cash flow as discussed by Jang [8] and Jang and Grandzol [9]. Furthermore, the large amount of investment needed for innovative activities requires firms to prioritize and manage their projects based on the commercial potential. Thus, there is a need to search for a new framework that can provide better explanations on innovation with respect to this issue. The most existing classifications of innovation are not based on the timing of financial outcomes of innovative activities.

One of the typologies regarding this topic is the categorization of radical and incremental innovation based on the sharpness of change in innovative practices [20]. A more drastic transformation can be expected from radical innovation projects while a relatively slight newness can be added to existing technologies during the incremental innovation process. Since radical innovation can pursue both drastic breakthrough and immediate commercialization, there exists the disparity between the distinction of radical and incremental innovation, the main focus of this paper. Space shuttle can be considered as an example of radical innovation as the realization of reusable spacecraft but it is generally considered as a product for immediate use rather than a long-term growth momentum. Such discrepancy leads researchers to develop a new categorization of innovation based on the expected timing of financial outcome.

The Code-Division Multiple Access (CDMA) wireless technology is an interesting case for this point. The CDMA technology was developed by Qualcomm (www.qualcomm.com), but the commercial CDMA phones were first created and produced by Korean manufacturers, including SE and LG. While Qualcomm was interested in 
developing CDMA as planting innovation, SE and LG focused on commercializing the technology for harvesting that innovation. Qualcomm could benefit from licensing fees in the long term with the success of commercial products based on CDMA. In contrast, the short-term cash flow was derived by SE and LG as they sold more CDMA phones to individual consumers.

From this perspective, innovation can be categorized based on its relatedness to the firm's performance in the short or long term $[8,9]$. While certain types of innovative activities may result in an increase of the firm resources engaged in the current competition, others can create value that has long-term potential. This approach modifies the definition of innovations by Gumusluoglu and Ilsev [21] as described in Jang [8] and Jang and Grandzol [9]. First, harvesting innovation can be described as the development of a new resource that can help launch new products/services in the short term. New products, such as Toyota Prius, would be a good example of this type of innovation. Planting innovation refers to the creation of potential firm resources that are based on the state-of-the-art innovation in the expectation of long-term financial benefits. For instance, the invention of hybrid engine technology "plants" potential for future value while the creation of a hybrid car like Prius "harvests" the results of the planting of that innovation.

There are several reasons why planting innovation may not result in new commercial products/services in the short term. First, there may be social constraints that would not allow the use of innovative technology, resulting in no market for new products/services. The commercial use of human stem cell research in the USA has been prohibited by the Food and Drug Administration [22]. Firms initiating planting innovation in this area cannot expect commercial success due to this regulation, except perhaps in other countries. Second, firms may need to wait for the advent of other complementing technologies for the commercialization process. Thus, firms face a high degree of uncertainty about the financial outcome of planting innovation in the long term, especially in the biotech industry. The development of a new technology usually has a high probability of failure. Therefore, planting innovation may not lead to financial gains in the short term even if firms succeed in developing a technology.

The characteristic of planting innovation makes it distinct from invention. Innovation requires entrepreneurial utilization of technological newness by definition, while invention includes scientific and/or technological breakthrough for discovery purposes [23]. Firms invest in planting innovation projects in the expectation of long-term profits. Although the result of planting innovation may directly create cash flows in the form of patent fee, firms usually wait until finding out how to apply the result of planting innovation. In contrast, harvesting innovation pursues shortterm profits by launching new products or services. In the 1970s, the Palo Alto Research Center (PARC) at Xerox initiated the development of innovative technologies such as Ethernet (or LAN technology) and copper wire-based Ethernet communication [24]. Due to the lack of commercial intention of Xerox both short and long term, these developments can be classified as examples of invention rather than planting innovation.

Given the heterogeneous characteristics of planting and harvesting innovation, ambidexterity can be important in balancing such innovative activities. Studies on 
exploitative and explorative innovations have examined this issue $[6,7,25]$. Since pioneering efforts for new processes or technology involve much risk, firms need to optimize the return of their investment in both types of innovation. One possible approach is to utilize external capabilities through M\&A, alliances, or industryacademia collaborations through open innovation. Such arrangements would allow firms to share the risk of innovation with other participants [1].

In addition, convergence has played a major role in explaining value added activities in modern firms [1, 26]. Globalization has encouraged the convergence revolution which allows value creation from the synergy of diverse disciplines, industries including IT, biotechnology, and nanotechnology [26]. The co-innovation platform helps converge diverse types of innovations for value creation [1]. Multinationals participating in co-innovation are expected to collaborate with stakeholders, including suppliers, customers, partners, and outsiders. Therefore, outside stakeholders can be active partners who co-create shared goals.

Overall, the classification of innovation can contribute to research by providing clearer guidelines related to the timing of financial outcome of innovation. While planting innovation can result in potential resources for long-term value creation, harvesting innovation is intended to generate continuous cash flows to those engaged in the current market. Following the case of exploitative and explorative innovation, researchers in this field should also consider ambidexterity of the organization. By doing so, firms under resource constraints can be prepared for an optimal portfolio of innovation projects, resulting in better organizational performance in the long term.

\section{Case analysis}

In this study, the case of Samsung Electronics (SE), now the largest electronic firm in the world from a former emerging economy, is examined to unveil the processes of harvesting and planting innovation and their results. Innovative activities have been the core strength of SE and are expected to continue creating value for SE. The Mission 2020 of Samsung (http://www.samsung.com) states that it will "inspire the world, create the world" through creative and innovative solutions. This implies that the firm intends to pursue innovation over time beyond the development of commercial products for short-term returns.

Several qualitative techniques are employed to investigate the SE case. First, we collected articles including executive interviews from 2000 to 2012. The articles were manually coded into planting and harvesting innovation frameworks after a careful review of contents. News reports were analyzed via local portal sites, including LexisNexis (http://www.lexisnexis.com) and Naver (www.naver.com). Particularly, we searched Naver, the major Korean portal website, to collect news articles concerning SE research topics from 2002 to 2012. We chose this period, 2002 and 2012, to collect data for this study as this is when SE made the significant transformation to become a dominant global IT leader. The search keywords used were "Samsung Electronics" and "Innovation." The search using the keywords assured the study to verify that all related articles are captured. After removing duplicates, we investigated the contents of 183 related news articles. Based on the analysis, all the key interviews of executives and managers at SE were collected and examined. In addition, the other secondary data sources like the websites of companies, universities, and local governments were examined. 


\section{Samsung Electronics}

SE has been a major global player in electronics and related industries for over three decades. Hoovers (www.hoovers.com), a leading corporate information provider on large businesses, describes the overall state of this firm as the new "Electronics Samson." In year 2015 , it reported $\$ 171$ billion revenue and $\$ 16$ billion net profit. Its major products include digital electronics, semiconductors, and DVD players. Financial Times ranked Samsung Electronics as 19th in their 2015 FT Global 500 (www.ft.com/ft500). It is beyond doubt that this firm has been successful in creating value for its customers.

The webpage of Samsung Electronics (www.samsung.com) and Samsung C\&T (www. samsungcnt.co.kr) describes the history of Samsung Group and Electronics as follows. Samsung group was founded in 1938 as a small retail firm in Daegu, Korea. The founding chairman, Lee Byung-Chull, established Samsung-Sanyo Electronics to diversify the business in 1969. As the name implies, the firm collaborated with Japan's electronics giant Sanyo. It began production of black-and-white TV sets for the first time in 1970, as an outsource manufacturer. After changing its name to Samsung Electronics, the firm began to produce color TV sets, video recorders, microwaves, and personal computers. It has rapidly developed as a global firm since it entered the semiconductor industry in the early 1980s. Since South Korea has recently been accepted as a developed economy [27], it can be said that SE began as an emerging market firm.

Given the fact that SE was founded only about five decades ago, the current performance and growth are astonishing. Despite the current status, the firm used to be considered as a fast follower [28]. SE had focused on producing existing products with better quality at lower prices than other global firms. It is an interesting research topic to examine how and why SE has evolved into a global giant in the electronics industry.

To provide an explanation on this issue, we investigated how SE has implemented innovation to achieve strategic objectives. In 2001, President of Booz Allen and Hamilton Korea stated that Korean firms need to pursue breakthrough innovations to adapt to new market environments [29]. In other words, SE as well as other major Korean manufacturers began to pursue innovation rather than continue to follow market leaders to survive in the dynamic global marketplace.

\section{Harvesting innovation at Samsung Electronics}

SE has engaged in various innovation activities to gain global competitive advantage. By doing so, the firm has been able to create value and benefit from new markets with expectations of stable cash inflows. For instance, SE developed new products like Rambus DRAM and Nand flash memory rather than increasing the accumulation rate of semiconductors [28]. Since these new products reflect the needs of customers, including PC or smartphone manufacturers, the innovation brought a large amount of profit in the short term. Given the astonishing results that SE has accomplished, its process of harvesting innovation has drawn much attention.

SE has continued implementing innovative activities steadily. The Value Innovation Program (VIP) Centre, setup in 1998, has played a key role in developing innovative new products at SE $[28,30,31]$. This Centre has shown to nurture creativity and broaden the ideas of R\&D staff. As the chief researcher at SE stated, the introduction of value innovation methods has contributed to the creation of many new ideas [28]. 
Through this system, all participants were expected to overcome the trap of past success syndrome, leading to what is possible.

Blue Ocean Strategy (BOS) [32] has been the backbone of the harvesting innovation process at SE [30]. SE invited W. Kim, the main author of BOS, to train its executives. Senior executives have encouraged the dissemination of value innovation at SE based on the BOS approach [33]. SE strives to create value which its customers never even expected through value innovation for new products. SE's value innovation includes value management and value creation [33]. While the former focuses on cost reduction and efficiency improvement, the latter aims to generate added value. Therefore, the firm searches for creative ideas rather than implementing traditional continuous improvement type programs.

SE has found practical tools to implement harvesting innovation based on BOS [31]. First, the VIP Centre has utilized the strategy canvas, a framework of implementing BOS [32, 34]. In the Centre, managerial decisions on important projects have been made based on the value curve of each unit against competitors, resulting in new products like 40-inch LCD TV. In addition, the "7 Tools Method" practiced in Japan, which enables firms to empirically recognize value factors of their customers, was introduced [35]. For instance, a survey of 226 Japanese employees triggered the production of a laptop that works well even in a bad wireless environment. These types of techniques have helped SE create new products successfully by reflecting innate needs and requirements of individual and business customers.

It has been reported that all of the creative ideas from the VIP Centre have been reflected in the design and development of new products of SE [36]. As a result, innovativeness of the firm's new products has been globally recognized as the numerous Innovation Awards of the Consumer Electronics Association (CEA) attest (see Table 1). These achievements prove that the innovative results of SE have been widely recognized by professionals in the field as well as ordinary customers. SE has succeeded in developing new products through harvesting innovation activities.

\section{Planting innovation at Samsung Electronics}

SE has also focused on the creation of innovative ideas which may not realize any meaningful revenue in the short term. The major results of planting innovation are original technologies which can result in competitive advantage and lead to future business success. The CEO of SE stressed the importance of "technology preparation management," pursuing core technologies in order to respond to the convergence across technologies and products [37]. This statement exhibits the strong will of top management of SE to implement the planting innovation strategy.

The Samsung Advanced Institute of Technology (SAIT) has played a critical role in developing original technologies. The website (www.site.samsung.com) describes the research efforts currently in place. The Future IT and Convergence domain seeks technologies across real 3D processing, communication theory and network, multicore processing, data intelligence, and medical imaging. The New Materials and Nanotechnology domain aims at developing flexible electronics, solid state lighting, film ceramic crystal composite materials, micro-system integration, oxide materials and devices, spintronics, and nanostructure and materials research. The Energy and Environment 
Table 1 Representative CES innovation awards won by Samsung (2011-2016)

\begin{tabular}{|c|c|c|}
\hline Year & Representative CES innovation awards & Source \\
\hline 2011 & 512 GB SSD, 37 gigabyte Green DDR3 RDIMM & $\begin{array}{l}\text { https://www.samsung.com/semiconductor/ } \\
\text { insights/news-events/samsung-electronics- } \\
\text { honored-with-37-ces-2011-innovation-awards/ } \\
\text { (Samsung Newsroom CES 2011/accessed March 17, } \\
\text { 2019) }\end{array}$ \\
\hline 2012 & $\begin{array}{l}\text { LED UNES8000 TV, Plasma PNE8000 TV, ES7500 and } \\
\text { ES } 6800 \text { LED TVs }\end{array}$ & $\begin{array}{l}\text { https://news.samsung.com/global/ces-2012- } \\
\text { samsung\%e2\%80\%99s-flagship-led-and-plasma-tv } \\
\text { (Samsung Newsroom CES 2012/accessed March 17, } \\
\text { 2019) }\end{array}$ \\
\hline 2013 & $\begin{array}{l}\text { 85" UHD TV, Samsung Smart TV Camera, Smart LED } \\
\text { TV } 7500 \text { and } 8000 \text { series, EX2F Smart Compact } \\
\text { Camera, Samsung Induction Range with Flex } \\
\text { Cookzone, Galaxy SIll Smartphone, Galaxy Note } \\
\text { 10.1, Samsung Series } 9 \text { Premium Ultrabook, CLP- } \\
365 \text { W Laser Color Printer, 2GB LPDDR3 Mobile } \\
\text { DRAM Chip, DDR3 64GB LRDIMM }\end{array}$ & $\begin{array}{l}\text { https://news.samsung.com/global/samsung- } \\
\text { electronics-honored-with-27-ces-2013-innovations- } \\
\text { awards } \\
\text { (Samsung Newsroom CES 2013/accessed March 17, } \\
\text { 2019) }\end{array}$ \\
\hline 2014 & $\begin{array}{l}\text { Galaxy Gear, Curved OLED TV, T9000 Four-Door Re- } \\
\text { frigerator, Galaxy Note 10.1-2014 Edition, Galaxy } \\
\text { Note 8.0, Galaxy Tab } 3 \text { 8.0, Galaxy NX camera, DV } \\
457 \text { Front-Load Dryer }\end{array}$ & $\begin{array}{l}\text { https://news.samsung.com/global/samsung- } \\
\text { wins-24-ces-2014-innovations-awards- } \\
\text { accumulating-258-awards-in-10-years } \\
\text { (Samsung Newsroom CES 2014/accessed March 17, } \\
\text { 2019) }\end{array}$ \\
\hline 2015 & $\begin{array}{l}\text { JS9500 TV, 105-inch UN105S9B TV, Active Wash } \\
\text { Washing Machine, Flex Duo Dual Door Range, } \\
\text { Revolutionary Portable SSD T1, ATiv Book } 9\end{array}$ & $\begin{array}{l}\text { https://news.samsung.com/global/samsung- } \\
\text { electronics-honored-with-80-awards-at-ces-2015 } \\
\text { (Samsung Newsroom CES 2015/accessed March 17, } \\
\text { 2019) }\end{array}$ \\
\hline 2016 & $\begin{array}{l}\text { KS9500 Series Curved SUHD TV, 4-Door Flex Re- } \\
\text { frigerator with Family Hub, Front Load Washer with } \\
\text { AddWash, Galaxy TabPro S, Ultra-lightweight Note- } \\
\text { book 9, Palm-sized Portable SSD T3 }\end{array}$ & $\begin{array}{l}\text { https://news.samsung.com/us/samsung-electronics- } \\
\text { wins-100-awards-at-the-2016-consumer-electronics- } \\
\text { show/ } \\
\text { (Samsung Newsroom CES 2016/accessed March 17, } \\
\text { 2019) }\end{array}$ \\
\hline
\end{tabular}

domain focuses on energy storage, energy conversion, and environment fields. The Bio and Health domain explores gene analysis and point of care testing (POCT). Indeed, SE has encouraged researchers to create a broad range of intellectual capital for the purpose of leading future technologies.

Furthermore, it seems likely that SE seeks Chesbrough's $[2,38]$ open innovation to improve efficiency and effectiveness of planting innovation. By doing so, the firm can create innovative results with less burden in time and resources. The CEO mentioned that open innovation needs to be encouraged to shorten the technology life cycle and to enable convergence in the electronics industry [37]. Thus, SE senior managers have aggressively focused on the utilization of external ideas and capabilities [39].

M\&A has been a major instrument to acquire external intellectual capital. SE has acquired several firms, including SanDisk, Amica (a Polish electronics firm) in 2009, and Transchip (a non-memory semiconductor manufacturer in Israel) in 2008 [40]. SE informed the board of directors of SanDisk about its intention of collaborative innovation orientation and human resource retention in SanDisk [41]. Such M\&A activities have enabled SE to obtain proven and complimentary intellectual capital and dynamic capabilities, including R\&D employees.

SE has also managed a broader range of intellectual capital without much investment by sharing their proprietary technologies with partners. For example, SE and IBM, two top US patent firms, established a cross-licensing agreement which allows the participants to utilize each other's patents for innovation in 2011 [42]. These firms can share their patents without additional investment, resulting in a more stable basis for 
innovative activities. This type of contract enables SE to implement planting innovation with finite capabilities. Executives of SE and IBM also announced that the objective of cross-licensing lies in sharing intellectual capital in the expectation of continuous innovative outputs. In sum, SE has implemented planting innovation through SAIT internally and has utilized external capabilities through M\&A and licensing for significant financial gains in the long run. SAIT has implemented several major research projects independently as well.

\section{Ambidexterity and co-innovation}

Since SE is implementing planting and harvesting innovation simultaneously, one major task is balancing both types of innovative activities. Otherwise, the firm may suffer from lack of financial cash flows or future leadership in the industry. Despite their brand image, major manufacturers of wristwatch had to overcome the loss of sales volume in the 1970s due to the revolutionary quarts movement technology [43]. Although US electronic giants initiated the transistor technology, Japanese manufacturers like Sony harvested the lion's share of its benefits with their transistor radios [44].

The significance of inter-organizational cooperation in attaining competitive advantage cannot be ignored [45]. Thus, any organization, however large or global it may be, cannot be competitive for long without collaboration with other world-class partners. From this perspective, the success or failure of firms today lies in managing the relationships with other value chain partners and stakeholders [4].

Beyond the conventional exploration and open innovation focusing on the use of external resources, SE has been searching for the best way to simultaneously implement planting and harvesting innovation through co-innovation with stakeholders [1] (see Fig. 1). The main focus of the VIP Centre has been on how to encourage collaboration among internal departments. Resulting convergence across departments has enabled the firm to recognize the diverse viewpoints other than the opinions of core engineers. The VIP Centre director stated that those firms interested in value innovation need to adopt the cross-functional team (CFC) concept

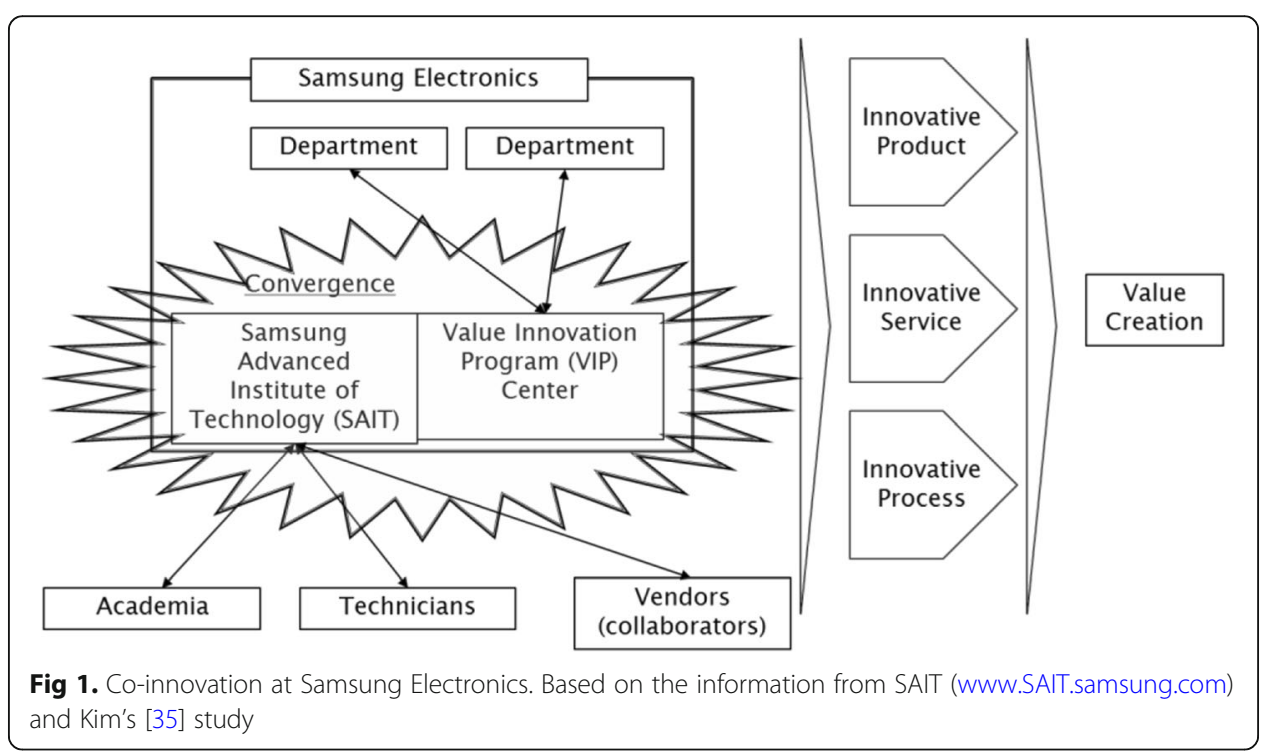


with a separate space to promote inter-departmental collaboration for value innovation [34]. This process is expected to encourage formal and informal sharing of ideas, opinions, and viewpoints since participants have more opportunities to communicate with many people. For instance, the CFC team consisting of marketers, designers, and engineers developed a new slim style laptop which caught the fancy of Japanese consumers [35]. Furthermore, the members of the Centre frequently collaborate with external partners [35].

SAIT has played a significant role in connecting SE with external entities (http:// www.sait.samsung.co.kr), such as universities, through the Global Research Outreach (GRO) program and other collaborators via the Collaborative Open Research Expert (CORE) program. These efforts have allowed the firm to share the risks inherent in planting innovation. Thus, the firm has been able to reduce the uncertainty involved in innovative practices and maximize its value with finite organizational resources.

Another example of collaboration lies in its value-chain management beyond the use of external capabilities. An association of Samsung's collaborating vendors, Hyup-SungHoe, has played a key role in co-innovation processes [46]. SE and collaborating vendors have participated in innovation activities, including sectional committee meetings. It is evident that SE's innovation activities cover not only its own value chain but also that of its partners. Given the fact that current business activities must include vendors, the improvement of innovation capabilities of the entire value chain is essential for gaining competitive advantage. SE also considers the creation of new ventures with excellent technologies as another outcome of its open innovation strategy [47]. The firm manages its entire value chain to compete successfully, as opposed to conducting business with partners for short-term monetary rewards. Figure 1 presents SE's value chain convergence activities.

SE has participated in the various industry-academia collaboration projects. This partnership has enabled SE to interact with partners to utilize their tangible and intangible resources. Particularly, research universities can provide professional human resources, research expertise, and infrastructure. In 2012, SE established the Centre for Intelligent Computing (CIC) with Seoul National University [48]. While the former supports the facilities and programs, the latter provides research ideas and its faculty resource. Such projects allow SE to benefit from the results of collaborative innovation while sharing the burden of investment. Furthermore, individual participants would likely to share ideas and opinions due to their "relationships" even after the official project is completed, beyond organizational boundaries. SE has also established the Samsung Talent Program (STP) with 14 Korean universities [48]. This program is intended to nurture and develop $R \& D$ employees to fit its needs.

The use of a co-innovation mechanism has played a key role in managing planting and harvesting innovation with limited organizational resources. SE has established networks with the various innovation partners, including diverse internal departments, academia, technicians, customers, and suppliers to collaborate and cocreate for shared goals. In addition to external resources, the closely interconnected relationships among participants are expected to nurture collective intelligence. Overall, co-innovation allows SE to manage both types of innovation, harvesting and planting, while coping with its fast expanding global presence. 


\section{Firm performance}

The innovation investment of Samsung Electronics has shown tremendous financial return as can be seen in Fig. 2. The financial information from Daum (www.daum.net), a major portal site in Korea, exhibits that SE's sales volume has dramatically increased since the early 2000s. As SE has paid more attention to harvesting innovation, its sales volume surged from 2001 to 2004. This implies that the firm continued its growth by actively pursuing innovative activities which created much financial gain in the short term.

The revenue of the firm diminished drastically in 2007 with the global financial crisis. This "earning shock" was due to the decrease of demands for LCDs and semiconductors [49]. The global economy was in recession for several years afterward. For example, in 2012, the Federal Reserve Bank announced that the net asset of median family in the USA decreased by 38.8\% from December 2007 to June 2009 [50]. Given that the consumption of middle-class families in the USA has been the locomotive of global economy for decades, the effect of the macro-economic crisis would be challenging for many global firms.

SE executives began to search solutions for the creation of original technologies, while continuing its innovation harvesting efforts. Despite the global financial crisis, SE has continued its growth [50]. In 2017, the revenue was approximately $\$ 224$ billion [51]. SE has steadily expanded its business after it introduced harvesting and planting innovation despite the hostile macro-economic environment and recent ownership succession.

\section{Discussion and evaluation}

This study investigated planting and harvesting innovation to answer the research question, "Which classification of innovation best explains the heterogeneous timing of

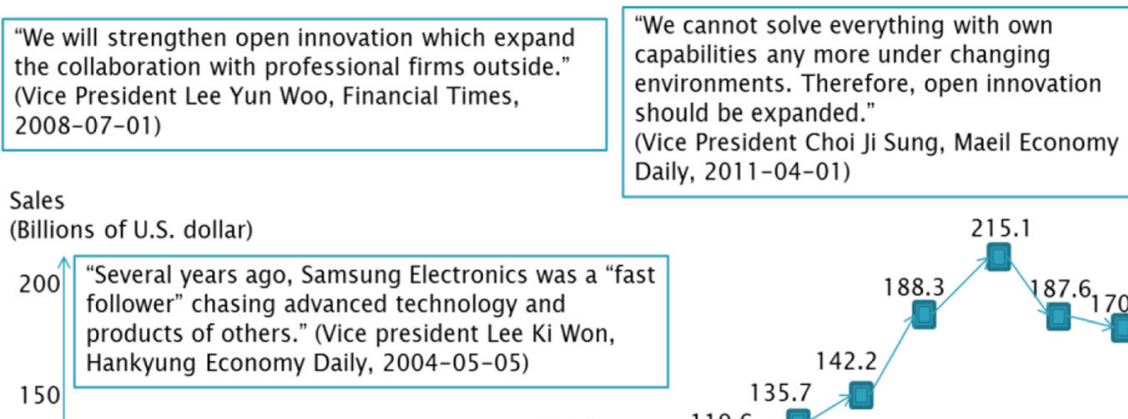

"We cannot solve everything with own capabilities any more under changing environments. Therefore, open innovation should be expanded."

(Vice President Choi Ji Sung, Maeil Economy Daily, 2011-04-01)

215.1 
revenue realization?" While harvesting innovation seeks commercial results in a relatively short term, planting innovation pursues the development of new ideas and technologies for a long term. For instance, a firm with the CDMA wireless technology may not succeed financially without the dispersion of CDMA phones. Given the finite amount of resources, firms need to efficiently balance planting and harvesting innovation. Otherwise, they would fail to develop both new products/services for market launching and original technologies for future market expansion while continuing their business activities.

A case analysis was employed to answer the second research question, "How are planting and harvesting activities of innovation implemented in a successful global business firm?" Samsung Electronics (SE) was chosen as a case study since it has become the largest electronics firm in the world but originated from a former emerging economy, South Korea. Despite its limitations, SE continued to grow by using innovation as a vehicle to move from an outsourcing firm to a global leader in innovation. It is a dramatic success story for a local firm in Korea which began its business in the 1970s. Since SE established innovation as the core of its business activities in its mission statement, it has implemented the dual strategy of planting and harvesting innovation.

SE has participated in various activities to develop innovative new technologies as well as products. The interviews reported were collected from news articles to analyze the stream of innovative activities of SE. Harvesting innovation has led to the initiation of a broad range of new products, allowing the firm to access global customers and also received world-renowned innovation awards. SE has also focused on planting innovation which can result in original technologies. Based on Blue Ocean Strategy, the Value Innovation Program (VIP) Centre has been primarily responsible for developing new products. The Samsung Advanced Institute of Technology (SAIT) pursues original technologies which can continuously support technological leadership in the years to come.

Co-innovation [1] has enabled SE to focus both planting and harvesting innovation activities with limited resources. External collaborators have contributed to the application of SE's tacit knowledge for convergence that is difficult to imitate by competitors. The VIP Centre and SAIT have played a critical role in encouraging collaboration among innovation value chain partners, including academic researchers, technicians, vendors, and customers to co-create value. It has enabled the firm to pursue innovative outcomes while managing financial stability. The financial performance of SE exhibits that its innovation activities have resulted in a remarkable success.

\section{Conclusions}

The digital age is characterized by the increased complexity and uncertainty of the business environment [1]. In the environment of increasing velocity of change, business firms must develop dynamic capabilities through innovation to adapt to change with agility, flexibility, and speed [4]. There have been various innovation approaches in the literature: exploitative vs. explorative [7], disruptive [52] vs. non-disruptive [53], ambidexterity [54], and convergence innovation [55]. However, the purpose of innovation remains the same, which is to create new or added value by applying ideas or technologies in a fundamentally different way [1]. What is not widely known is that innovation is not one integrated process. Instead, there are several steps and cycles in innovation. Planting innovation involves creating new ideas, scientific breakthroughs, or new technologies. Planting seeds 
does not guarantee a good harvest. Many nurturing steps such as careful planning, risk taking, and entrepreneurship are needed to have a successful harvest. Thus, studying the most spectacular success transformation case of SE through its innovation process provides meaningful theoretical and practical insights and a contribution to the literature of innovation.

This study is not free from limitations. Although SE can be considered as one of global leading innovators originated from Korea, a success story from one of the poorest countries in the world to an advanced economy, the generalizability of the single case study can be limited as Tversky and Kahneman [56] suggested. Future researchers should conduct relevant studies in various contexts to overcome such limitation. In addition, the qualitative analysis tool of Gibbert et al. [57] can be used to lessen the concern on generalizability.

There are many factors that have contributed to the success of SE. In this study, we used the revenue as the reference of SE's efforts of harvesting innovation. There could be many other factors that contributed to the performance of SE. However, we believe these factors all contributed to the combined efforts of SE in harvesting innovation.

In addition, it is also expected that future studies may apply more refined research methods to examine the process and consequences of planting and harvesting innovation. While we believe in the merits of the research method applied in this study, it is also possible that executives might have exaggerated the process and outcomes of their projects. Future researchers are expected to cross-check the results of planting and harvesting innovation by utilizing multiple research methods.

Despite the limitations, this research provides several meaningful implications. It uses a distinction of planting and harvesting innovation $[8,9]$ to examine how a firm grows into a global leader despite its finite managerial and financial resources. While planting innovation aims to implement technological advancement as a potential source of longterm profits, harvesting innovation focuses on the development of new products for market expansion in the short term. The framework of planting and harvesting innovation is expected to provide a tool for managers to distribute limited funds for various types of innovation projects. It shall enable them to clarify whether the current focus of innovation investment lies in launching new innovative products or seeking competitive advantage for future profits. The case of Samsung Electronics exhibited that its innovation has focused on both short-term profits and technological innovation for the future growth momentum. Firms are recommended to follow this notion to compete successfully in high tech industries with limited financial, technological, and managerial competencies.

Collaboration is also required for firms seeking both planting and harvesting innovation. Given their shortage of resources and competencies, firms need to share the risks and the burdens of innovation projects with external partners. Following the case of Samsung, they are expected to cooperate with various entities, including research institutions, suppliers, customers, or new ventures. It enables firms to afford the cost of breakthrough innovation despite their finite resources and experiences. Collaboration helps these firms create innovation results for advanced as well as emerging economies.

This study also provides implications from methodological perspectives (Table 2). The use of indirect interviews from news articles allowed us to observe the opinions of SE executives over time. In addition, it can collect the opinions of executives at the 
Table 2 Implications of the study results

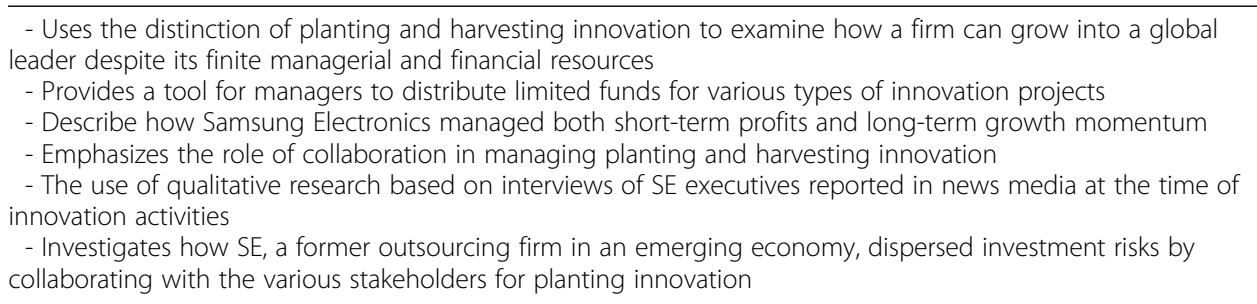

time of innovative activities rather than asking current employees' perceptions about what happened in the past. It provides future researchers with an effective method for exploratory research. The use of this underused but promising methodology can contribute to overcoming the limitations of research in the management field despite its possible limitations.

Practitioners can obtain lessons from the results of this study. They could observe how $\mathrm{SE}$, a former emerging market firm, dispersed investment risks by collaborating with the various stakeholders to implement planting innovation. The convergence of internal and external ideas, from suppliers, academia, other businesses, and customers, is essential for the implementation of both types of innovation with finite resources. Furthermore, they need to nurture innovative capabilities of entire internal and external stakeholders as coinnovators. This shall allow firms to achieve the network effect of innovation.

As suggested by Lee [4], the main focus of innovation projects has been on how to benefit business activities in new ways. Lee [58] and Schniederjans and Schniederjans [59] also examined how practical operational issues like quality practices can be improved by innovation.

\begin{abstract}
Abbreviations
BOS: Blue Ocean Strategy; CEA: Consumer Electronics Association; CFC: Cross-functional team; CIC: Centre for Intelligent Computing; CORE: Collaborative Open Research Expert; GRO: Global Research Outreach; PARC: Palo Alto Research Center; POCT: Point of care testing; SAIT: Samsung Advanced Institute of Technology; SE: Samsung Electronics; CDMA: Code-Division Multiple Access; STP: Samsung Talent Program; VIP: Value Innovation Program
\end{abstract}

\title{
Authors' contributions
}

All authors contributed to the developing of the manuscript. All authors read and approved the final manuscript.

Funding

There was no funding support for this study.

\section{Availability of data and materials}

The datasets used and/or analyzed during the current study are available from the corresponding author on reasonable request.

\section{Competing interests}

The authors declare that they have no competing interests.

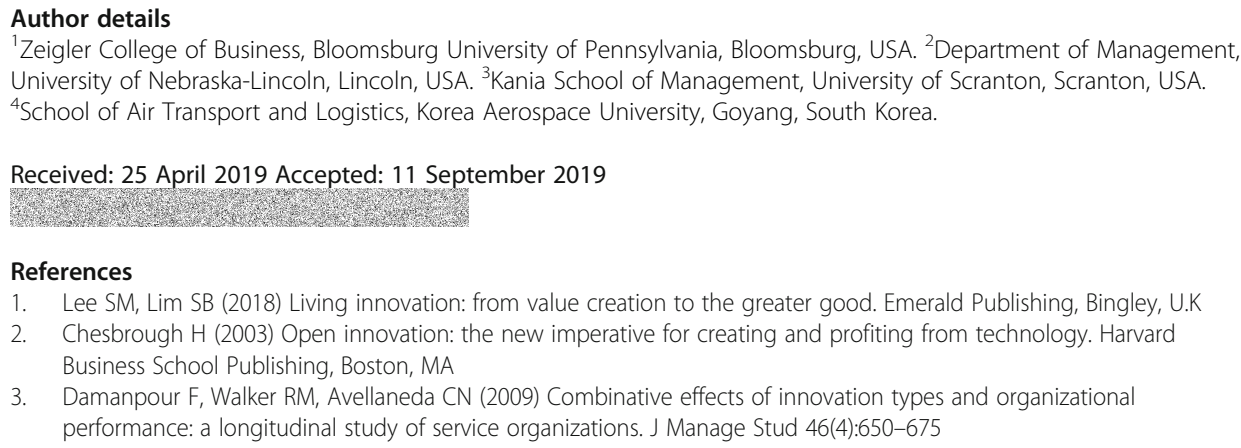

1. Lee SM, Lim SB (2018) Living innovation: from value creation to the greater good. Emerald Publishing, Bingley, U.K

2. Chesbrough $\mathrm{H}$ (2003) Open innovation: the new imperative for creating and profiting from technology. Harvard Business School Publishing, Boston, MA

3. Damanpour F, Walker RM, Avellaneda CN (2009) Combinative effects of innovation types and organizational performance: a longitudinal study of service organizations. J Manage Stud 46(4):650-675 
4. Lee SM (2018) Innovation: from small "i" to large "I". Int J Quality Inno. 4(1). https://doi.org/10.1186/s40887-018-0022-4

5. Lawson B, Samson D (2001) Developing innovation capability in organizations: a dynamic capabilities approach. Int Innov Manage 5(3):377-400

6. He Z-L, Wong P-K (2004) Exploration vs. exploitation: an empirical test of the ambidexterity hypothesis. Organ Sci 15(4): 481-494

7. March J (1991) Exploration and exploitation in organizational learning. Organ Sci 2(1):71-87

8. Jang S H (2012) Ownership structure, absorptive capacity, and innovation: planting vs harvesting innovation (doctoral dissertation). Retrieved from http://digitalcommons.unl.edu/businessdiss/29/

9. Jang SH, Grandzol C (2014) Value co-creation in emerging economies: planting and harvesting innovation perspectives. Int J Serv Sci 5(3/4):171-181

10. Teece DJ (2014) The foundation of enterprise performance: dynamic and ordinary capabilities in an (economic) theory of firms. Acad Manage Perspect 28(4):324-338

11. Gopalakrishnan S, Damanpour F (1997) A review of innovation research in economics, sociology, and technology management. Omega 25(1):15-28

12. Nohria N, Gulati R (1996) Is slack good or bad for innovation? Acad Manage J 39(5):1245-1264

13. Johannessen JA, Olsen B, Lumpkin GT (2001) Innovation as newness: what is new, how new, and new to whom? Eur J Innov Manage 4(1):20-31

14. Damanpour F, Szabat KA, Evan WM (1989) The relationship between types of innovation and organizational performance. J Manage Stud 26(6):587-602

15. Van de Ven AH (1986) Central problems in the management of innovation. Manage Sci 32(5):590-607

16. Rogers M (1998) The definition and measurement of innovation. Working Paper. Melbourne Institute of Applied Economic and Social Research, Melbourne, Australia

17. Rosenbusch N, Brinckmann J, Bausch A (2011) Is innovation always beneficial? A meta-analysis of the relationship between innovation and performance in SMEs. J Bus Venturing 26(4):441-457

18. Stieglitz N, Heine K (2007) Innovations and the role of complementarities in a strategic theory of the firm. Strateg Manage J 28(1):1-15

19. Teece D (1986) Profiting from technological innovation: implications for integration, collaboration, licensing and public policy. Res Policy 15(6):285-305

20. Dewar R, Dutton J (1986) The adoption of radical and incremental innovations: an empirical analysis. Manage Sci 32(11): $1422-1433$

21. Gumusluoglu L, Ilsev A (2009) Transformational leadership, creativity, and organizational innovation. J Bus Res 62(4):461-473

22. Halme DG, Kessler DA (2006) FDA regulation of stem-cell based therapies. New Engl J Med 355(16):1730-1735

23. Schmookler J (1966) Invention and economic growth. Harvard Business School Press, Cambridge, MA

24. Chesbrough H, Rosenbloom RS (2002) The role of business model in capturing value from innovation: wvidence from Xerox Corporation's technology spin-off companies. Ind Corp Change 11(3):529-555

25. Simsek Z (2009) Organizational ambidexterity: towards a multilevel understanding. J Manage Stud 46(4):597-624

26. Lee SM, Olson DL, Trimi S (2010) The impact of convergence on organizational innovation. Organ Dyn 39(3):218-225

27. Park Y, Lee JY, Hong S (2011) Effects of international entry-order strategies on foreign subsidiary exit. Manage Decis 49(9):1471-1488

28. Song D (2004a) Open the era of value innovation: (3) the case of Samsung Electronics. Hankyung Business Daily (April 19) Retrieved from http://news.naver.com/main/read.nhn?mode=LSD\&mid=sec\&sid1=101\&oid=015\&aid=0000701971

29. Hwang I (2001) No future for Korean firms: (1) technology imitation. Maeil Business Newspaper, September, 20 Retrieved from http://news.naver.com/main/read.nhn?mode=LSD\&mid=sec\&sid1=101\&oid=009\&aid=0000151003

30. Lee T (2005) [Searching blue ocean] Large firms: Samsung Electronics, be a consumer. Hankyung Business Daily, October 10 Retrieved from http://www.hankyung.com/news/app/newsview.php?aid=2005100701291

31. Lee T (2006) Korea innovation forum 2006: Samsung electronics VIP centre. Hankyung Business Daily, February 14 Retrieved from http://news.naver.com/main/read.nhn?mode=LSD\&mid=sec\&sid1=101\&oid=015\&aid=0000872791

32. Kim W, Maugborne W (2005) Blue ocean strategy: how to create uncontested market space and make the competition irrelevant. Harvard Business School Press, Boston, MA

33. Song D (2004b) Open the era of value innovation: (5) VI from executives. Hankyung Business Daily, May 5 Retrieved from http://news.naver.com/main/read.nhn?mode=LSD\&mid=sec\&sid1=101\&oid=015\&aid=0000706660

34. Song D (2005) Toward the blue ocean: an interview with Lee Dong Jin, a VIP centre Vice President at Samsung Electronics. Hankyung Business Daily, November 8 Retrieved from http://news.naver.com/main/read.nhn?mode= LSD\&mid=sec\&sid 1=101\&oid=015\&aid $=0000848475$

35. Kim M (2004) The era of value innovation: (4) VI embedded in Samsung. Hankyung Business Daily, May 4 Retrieved from http://news.naver.com/main/read.nhn?mode=LSD\&mid=sec\&sid1=101\&oid=015\&aid=0000706224

36. Kim Y (2007) Samsung value innovation program (VIP) centre. Financial News, November 4 Retrieved from http://news. naver.com/main/read.nhn?mode $=$ LSD\&mid=sec\&sid $1=101 \&$ oid $=014 \&$ aid $=0000355858$

37. Yang H (2008) Samsung Electronics Vice President Lee Yun Woo: initiate future core technologies. Financial News, July 1 Retrieved from http://www.fnnews.com/news/200807011810110422?t=y

38. Chesbrough H (2012) Open innovation: where we've been and where we're going. Res Techno Manage 55(4):20-27

39. Lee D (2011) Samsung Electronics Vice President Choi Jisung: respond early to even natural disasters. Daily Maekyung, April 1 Retrieved from http://news.naver.com/main/read.nhn?mode=LSD\&mid=sec\&sid1=101\&oid=009\&aid=0002439029

40. Jin S (2009) Samsung takes over Polish Amica. Moneytoday December 22 Retrieved from http://news.naver.com/main/ read.. hn? mode $=$ LSD\&mid $=$ sec\&sid $1=101 \&$ oid $=008 \&$ aid $=0002254573$

41. Kim B (2008) Samsung Electronics announces proposal for combination with SanDisk in letter to board of directors. Moneytoday, September 17 Retrieved from https://news.naver.com/main/read.nhn?mode=LSD\&mid=sec\&sid1=101 \&oid=008\&aid $=0002034388$

42. Yonhap (2011) AsiaNet: Samsung Electronics and IBM announce patent cross-license agreement. February 9 Retrieved from https://news.naver.com/main/read.nhn?mode=LSD\&mid=sec\&sid1=104\&oid=001\&aid=0004904103

43. Barrett ME (2000) Time marches on: the worldwide watch industry. Thunderbird Int Bus Rev 42(3):349-372 
44. Lynn LH (1998) The commercialization of the transistor radio in Japan: the functioning of an innovation community. IEEE T Eng Manage 45(3):220-229

45. Dyer JH, Singh H (1998) Relational view: cooperative strategy and sources of interorganizational competitive advantage. Acad Manage Rev 23(4):660-679

46. Kim C (2009a) Collaborating vendors benefit from Samsung Electronics. Maekyung Economy, August 23 Retrieved from http://news.naver.com/main/read.nhn?mode=LSD\&mid=sec\&sid1=101\&oid=024\&aid=0000026894

47. Kim M (2009b) Samsung embraces ventures. Munhwailbo, November 4 Retrieved from https://news.naver.com/main/ read. $n h n ?$ mode $=L S D \&$ mid $=$ sec\&sid $1=101 \&$ oid $=021 \&$ aid $=0002013900$

48. Park Y (2012) Industry-academia collaboration, 'upgrade.' Economic Review. In: March 9 Retrieved from http://www. econovill.com/archives/39043

49. Park S (2007) The bad performance of Samsung Electronics in the first quarter, Why? Sekyeilbo, April 14 Retrieved from http://news.naver.com/main/read.nhn?mode=LSD\&mid=sec\&sid1=101\&oid=022\&aid=0000220925

50. Bae B, Go S (2012) The middle class in Korea and U.S. was demolished as the result of the global financial crisis in 2008. Kukminilbo, June 12 Retrieved from https://news.naver.com/main/read.nhn?mode=LSD\&mid=sec\&sid1=101\&oid=005 \&aid $=0000514948$

51. Hoover's Company Records (2019) Samsung Electronics Co., Ltd. In-depth Records, January 23 Retrieved from https:// advance-lexis-com.proxy-bloomu.klnpa.org/api/document?collection=company-financial\&id=urn:contentltem:5H1POGF1-JBPR-X276-00000-00\&context=1516831

52. Christensen CM, Rayner M, McDonals R (2015) What is disruptive innovation? Harvard Bus Rev 93(12):44-53

53. Kim WC, Maubourgne R (2019) Nondisruptive creation: rethinking innovation and growth. MIT Sloan Manage Rev Spring:46-56

54. O'Reilly CA, Tushman ML (2013) Organizational ambidexterity: the past, present, and future. Acad Manage Perspect 27(4):324-338

55. Lee SM, Olson D (2010) Convergenomics: strategic innovation in the convergence era. Gower, Surrey, UK

56. Tversky A, Kahneman D (1986) Rational choice and the framing of decisions. J Bus 59(4):251-278

57. Gibbert M, Ruigrok W. Wicki B (2008) What passes as a rigorous case study? Strategic Manage J 29(13):1465-1474

58. Lee D (2015) The effect of operational innovation and QM practices on organizational performance in the healthcare sector. Int J Quality Inno 1(1). https://doi.org/10.1186/s40887-015-0008-4

59. Schniederjans D, Schniederjans M (2015) Quality management and innovation: new insights on a structural contingency framework. Int J Quality Inno 1(1). https://doi.org/10.1186/s40887-015-0004-8

\section{Publisher's Note}

Springer Nature remains neutral with regard to jurisdictional claims in published maps and institutional affiliations.

\section{Submit your manuscript to a SpringerOpen ${ }^{\circ}$ journal and benefit from:}

- Convenient online submission

- Rigorous peer review

- Open access: articles freely available online

High visibility within the field

- Retaining the copyright to your article

Submit your next manuscript at $\boldsymbol{\nabla}$ springeropen.com 